\title{
Peltophorum Africanum, a Traditional South African Medicinal Plant, Contains an Anti HIV-1 Constituent, Betulinic Acid
}

\author{
Andros Theo, ${ }^{1}$ Tracy Masebe, ${ }^{2}$ Yasuhiro Suzuki, ${ }^{1}$ Haruhisa Kikuchi, ${ }^{3}$ \\ Shoko Wada, ${ }^{3}$ Chikwelu Larry Obi, ${ }^{4}$ Pascal Obong Bessong, ${ }^{2}$ Motoki Usuzawa, ${ }^{1,5}$ \\ Yoshiteru OShima ${ }^{3}$ and TOSHIO HATtori ${ }^{1}$ \\ ${ }^{1}$ Laboratory of Emerging Infectious Diseases, Internal Medicine, Graduate School of Medicine, Tohoku University, \\ Sendai, Japan \\ ${ }^{2}$ Department of Microbiology, University of Venda, Thohoyandou, Limpopo Province, South Africa \\ ${ }^{3}$ Graduate School of Pharmaceutical Sciences, Tohoku University, Sendai, Japan \\ ${ }^{4}$ Academic and Research Directorate, Walter Sisulu University, Nelson Mandela Drive, Mthatha, Eastern Cape, \\ South Africa \\ ${ }^{5}$ Japan Foundation for AIDS Prevention, Tokyo, Japan
}

The biodiversity of medicinal plants in South Africa makes them rich sources of leading compounds for the development of novel drugs. Peltophorum africanum (Fabaceae) is a deciduous tree widespread in South Africa. The stem bark has been traditionally employed to treat diarrhoea, dysentery, sore throat, wounds, human immunodeficiency virus/ acquired immune deficiency syndrome (HIV/AIDS), venereal diseases and infertility. To evaluate these ethnobotanical clues and isolate lead compounds, butanol and ethyl acetate extracts of the stem bark were screened for their inhibitory activities against HIV-1 using MAGI CCR5+ cells, which are derived from HeLa cervical cancer cells and express HIV receptor CD4, a chemokine receptor CCR5 and HIV-LTR- $\beta$ - galactosidase. Bioassay-guided fractionation using silica gel chromatography was also conducted. The ethyl acetate and butanol extracts of the stem bark of Peltophorum africanum showed inhibitory activity against HIV-1, CXCR4 (X4) and CCR5 (R5) tropic viruses. The ethyl acetate and butanol extracts yielded previously reported anti-HIV compounds, (+)-catechin, a flavonoid, and bergenin, a C-galloylglycoside, respectively. Furthermore, we identified betulinic acid from the ethyl acetate fraction for the first time. The fractions, which contained betulinic acid, showed the highest selective index. We therefore describe the presence of betulinic acid, a not well-known anti-HIV compound, in an African medicinal herb, which has been used for therapy, and claim that betulinic acid is the predominant anti-HIV-1 constituent of Peltophorum africanum. These data suggest that betulinic acid and its analogues could be used as potential therapeutics for HIV-1 infection. —— South Africa; Medicinal plants; HIV-1; Extracts; MAGI CCR5+ cells.

Tohoku J. Exp. Med., 2009, 217 (2), 93-99. (C) 2009 Tohoku University Medical Press

Human immunodeficiency virus (HIV) is currently one of the most serious infectious pathogens with devastating consequences. HIV is the causative agent of acquired immune deficiency syndrome (AIDS) (Barre-Sinoussi et al. 1983; Gallo et al. 1983) and is now pandemic. In 2005, UNAIDS estimated that 40 million people were infected worldwide, with 25 million in sub-Saharan Africa, while approximately 2.4 million deaths were attributed to AIDS in 2005. Southern Africa represents one of the sub regions hardest hit by HIV. Based on antenatal seroprevalence surveys, infection levels surpass 30 percent in Botswana, Lesotho, Malawi, South Africa and Swaziland, with Angola, Mozambique, Namibia, Zambia, and Zimbabwe having 5, 15, 18, 16 and 25 percent, respectively (UNAIDS. 2005;
Bessong and Obi 2006).

Highly Active Antiretroviral Therapy (HAART) is an effective form of treatment against HIV but is inadequate due to drug resistance (Gulick et al. 1997; Perelson et al. 1997; Francois and Hance 2004). Screening of plant extracts for antiretroviral activity is important because plant-derived anti-HIV compounds can inhibit replication of the virus by interfering with one or more of the ten steps of the HIV replicative cycle (Vlietinck et al. 1998; De Clercq 2000; Kong et al. 2003). The anti-HIV active compounds of plant origin possess diverse chemical structures, e.g. glycyrrhizin which has been studied in AIDS patients (Ito et al. 1988; Hattori et al. 1989). It is evident therefore that plants can be useful sources or leads for the discovery of

Received September 29, 2008; revision accepted for publication December 29, 2008.

Correspondence: Toshio Hattori, M.D., Division of Emerging Infectious Disease, Tohoku University School of Medicine, 1-1 Seiryomachi, Aoba-ku, Sendai 980-8574, Japan.

e-mail: hattori.t@rid.med.tohoku.ac.jp 
novel anti-HIV compounds.

The use of medicinal plants for treating HIV/AIDS and other opportunistic infections of bacterial, fungal, protozoan or viral etiology is widespread in South Africa. Patients seek medical attention from traditional healers for many reasons including financial and traditional ones (Morris 2002). In the case of HIV/AIDS, medicinal plants function by the direct inhibition of virus replication, boosting of the immune system, or having inhibitory properties against one or several opportunistic infections (Lall and Meyer 2001; Obi et al. 2002; Lall et al. 2003; Obi et al. 2003). However, information on the potential therapeutic effects of South African medicinal plants on HIV infection is still lacking. Previous studies by Bessong and Obi have shown that medicinal plants from South Africa have strong anti HIV-1 activity in vitro against reverse transcriptase and integrase (Bessong et al. 2005). In the present study, we therefore investigated the anti-HIV activity of extracts from the stem bark of Peltophorum africanum. We also attempted to isolate the lead compounds from these medicinal plant extracts. We demonstrated that Peltophorum africanum contains three lead compounds. However, the amount of the compounds may limit their clinical efficacy.

\section{Materials ANd Methods}

\section{Selection of plants}

The selection of plants was based on information from traditional healers.

\section{Identification and collection of plants}

The identification and preservation of plants collected at Vuwani, Vhembe district, Limpopo, South Africa were done by a botanist, Mr. P. Tshisikhawe, Department of Biological Sciences, University of Venda, South Africa.

\section{Drying of plants}

Plant materials were washed with distilled water and dried in an oven $\left(37^{\circ} \mathrm{C}\right)$ for two weeks. They were then chopped into small pieces and ground (scientific blender) to a fine powder.

\section{Preparation of crude extracts}

Crude extracts were prepared according to Bessong et al. 2004. Briefly, $200 \mathrm{~g}$ of powdered material were soaked in $1 \mathrm{~L}$ of methanol and left overnight on a Labcon platform shaker. The soaked plant material was filtered through a cheese cloth, and then through a funnel with qualitative Whatman filter paper No. 3 (W\&R, England, UK). The residue was extracted as described previously. The filtrates were then evaporated to dryness using a rotary evaporator (RE 200, Bibby Sterillin, LTD, UK) at $40^{\circ} \mathrm{C}$. The crude extracts were stored in the dark until further use.

\section{Fractionation and Isolation of Compounds}

\section{Fractionation of the extract of Peltophorum africanum}

This extract was then partitioned with ethyl acetate $(200 \mathrm{~mL} \times 3)$ and water $(200 \mathrm{~mL})$ to yield ethyl acetate solubles $(3.08 \mathrm{~g})$ and a water layer, which was extracted with $n$-butanol $(200 \mathrm{~mL} \times 3)$ to afford n-butanol solubles $(6.33 \mathrm{~g})$. The ethyl acetate solubles were chromatographed over silica gel 60 (70-230 mesh, Merck), and the column was eluted with hexane-ethyl acetate and ethyl acetate-methanol by increasing the polarity to give five fractions, PA-e-1 (161.2 $\mathrm{mg}$ ), PA-e-2 (140.6 mg), PA-e-3 (565.1 mg), PA-e-4 (1517.7 mg) and PA-e-5 (451.9 mg). The $n$-butanol solubles were also chromatographed over silica gel to give six fractions, PA-b-1 (16.4 mg), PA-b-2 (861.3 mg), PA-b-3 (426.6 mg), PA-b-4 (3436.2 mg), PA-b-5 (608.0 $\mathrm{mg})$ and PA-b-6 (47.4 mg).

\section{Identification of compounds}

PA-e-2 was further chromatographed over silica gel twice (elutant: chloroform-methanol $(49: 1)$ and toluene-ethyl acetate $(19: 1)$, respectively) to give crude betulinic acid $(49.6 \mathrm{mg}$ ), which was recrystallized from chloroform-methanol $(1: 1)$ to yield purified betulinic acid (23.5 mg) (Fig. 1). PA-e-4 was also chromatographed over silica gel three times (elutant: chloroform-methanol $(4: 1))$ to give (+)-catechin 3-O- $\alpha$-L-rhamnopyranoside (1.4 mg). PA-b-2 was chromatographed over silica gel (elutant: chloroform-methanol $(37: 3)$ ) to yield bergenin $(808.5 \mathrm{mg})$.

We also used glycyrrhizin (provided by Minophagen Company, Tokyo, Japan), which is known to inhibit HIV-1 replication in vivo and in vitro (Hattori et al. 1989; Takei et al. 2005), because both betulinic acid and glycyrrhizin belong to the triterpenoid group and have similar structures.

\section{Cell culture, and viruses}

MAGI CCR5+ cells were cultured in Dulbecco's Modified Eagle's Medium (DMEM) at $37^{\circ} \mathrm{C}$ and $5 \% \mathrm{CO}_{2}$ supplemented with $10 \%$ heat inactivated fetal bovine serum, $200 \mu \mathrm{g} / \mathrm{ml} \mathrm{G} 418,100 \mu \mathrm{g} / \mathrm{ml}$ hygromycin B and $100 \mu \mathrm{g} / \mathrm{ml}$ zeocin (complete medium) (Chackerian et al. 1997). Stocks of HIV-1 strain pNL4-3 (Adachi et al. 1986) (X4) and JRCSF virus (R5) (Takeuchi et al. 2002) were obtained from Drs. A. Adachi and Y. Koyanagi, respectively.

\section{Anti HIV-1 assay}

MAGI assay

MAGI CCR5+ cells are HeLa-derived cells that express HIV receptor CD4 coreceptors, CCR5 and CXCR4. This cell line contains an integrated copy of HIV-LTR fused to $\beta$-galactosidase (gal) reporter gene, and expresses $\beta$-gal in the presence of HIV tat (Chackerian et al. 1997). To estimate the anti-HIV-1 activities of the fractions, MAGI assays were performed as previously described with some modifications (Uchida et al. 1997). Briefly, MAGI CCR5+ cells in complete medium were plated $\left(1 \times 10^{4}\right.$ cells/well $)$ and cultured in 96-well, flat bottomed microculture plates. The culture medium was then replaced with fresh medium containing various concentrations of the fractions in duplicate. These fractions were suspended in dimethyl sulfoxide (DMSO) at a concentration of $50 \mathrm{mg} / \mathrm{ml}$ and then serially diluted with complete medium. The diluted virus was added 30 min later. The HIV-infected (10 ng of p24) or mock-infected MAGI CCR5+ cells were cultured with the extracts continuously present and no cell washing was performed throughout the culture. Cells were stained with chlorophenolred $\beta$-D-galactopyranoside (CPRG) as previously described (Felgner et al. 1993; Flosh et al. 1998). After 3 days of culture, the medium was removed and the cells were lyzed with $100 \mu 1$ of phosphate buffered saline (PBS) containing 1\% Triton X-100 for 30 $\mathrm{min}$ at room temperature. The cells were then incubated for $60 \mathrm{~min}$ at $37^{\circ} \mathrm{C}$ with $100 \mu \mathrm{l}$ of a staining solution containing $0.01 \mathrm{M} \mathrm{KH}_{2} \mathrm{PO}_{4}, 0.1$ $\mathrm{M} \mathrm{K}_{2} \mathrm{HPO}_{4}, 2 \mathrm{mM} \mathrm{MgCl}$ and $10 \mathrm{mM} \mathrm{CPRG}$. In cells infected with 
P. africanum $\mathrm{MeOH}$ extract (10.0 g)

Partitioned between ethyl acetate and $\mathrm{H}_{2} \mathrm{O}$
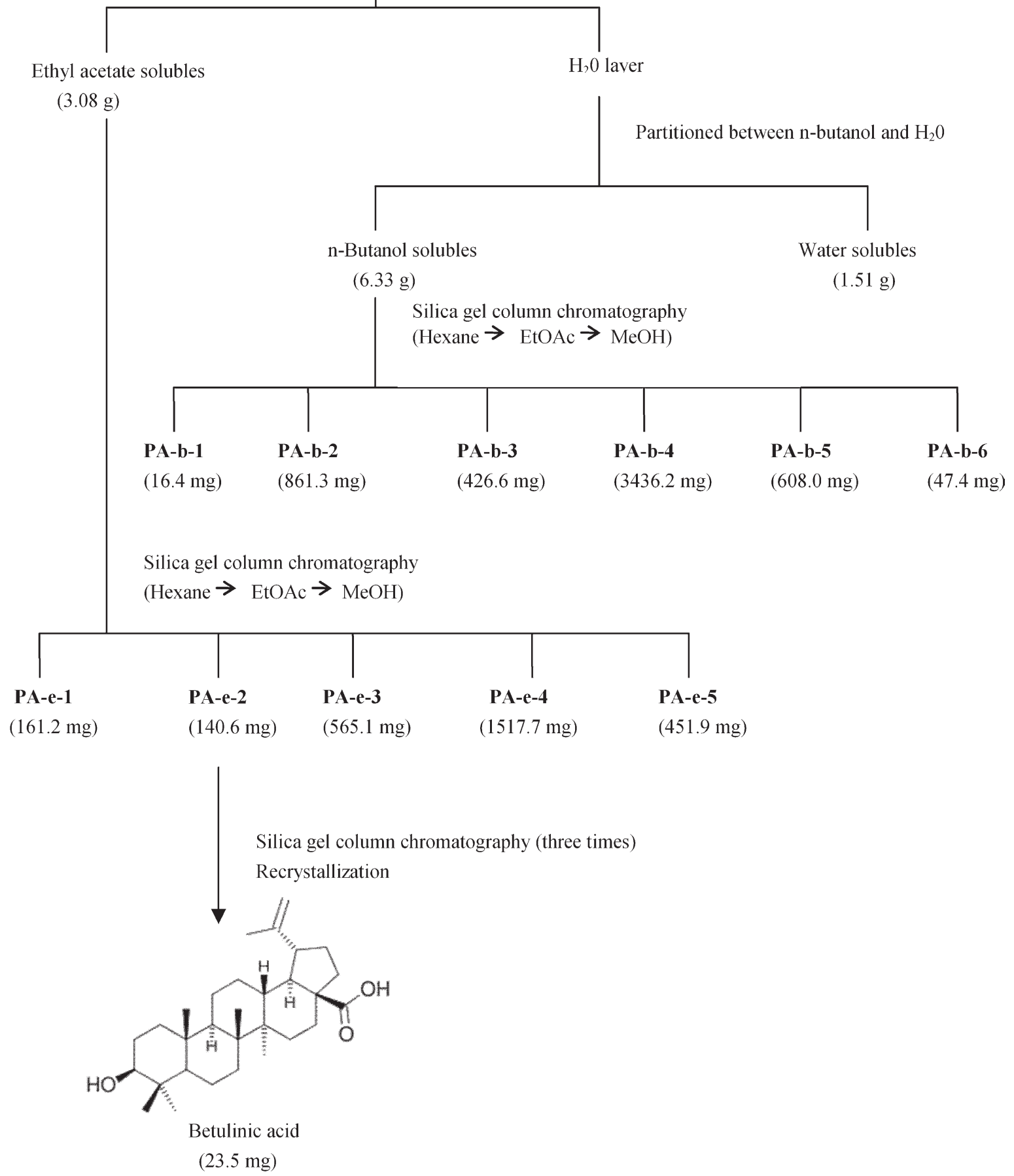

Fig.1. Fractionation procedures of Peltophorum africanum.

Bioassay fractionation of various fractions from the extracts $(10.0 \mathrm{~g})$ of Peltophorum africanum was performed using silica gel chromatography. n-Butanol solubles yielded fractions PA-b-1 to PA-b-6 whereas ethyl acetate solubles yielded fractions PA-e-1 to PA-e-5. Fraction PA-e-2 was chromatographed twice over silica gel to yield crude betulinic acid (49.6 $\mathrm{mg}$ ), followed by further recrystallisation to yield purified betulinic acid $(23.5 \mathrm{mg})$. 
HIV, the integrated HIV-LTR- $\beta$-gal reporter gene was expressed and the cells turned from yellow to brown on staining. Absorbances from the 96 well plates were then read at $570 \mathrm{~nm}$ in a microplate reader (Vmax, Molecular Devices, Sunnyvale, CA).

\section{Cytotoxicity assay}

Cytotoxic assays were performed as follows using cell counting kit-8 (Dojindo Com, Kumamoto, Japan). MAGI CCR5+ cells in complete medium were cultured in 96-well microculture plates at $1 \times$ $10^{4}$ cells/well for $24 \mathrm{~h}$. The culture medium was then replaced with fresh medium containing fractions in duplicate. After 3 days, cell viability was quantified according to the company's instructions.

The $50 \%$ inhibition concentration $\left(\mathrm{IC}_{50}\right)$ of the herbs was determined from a curve relating the percentage inhibitory activities to the concentration of the herbs. The $50 \%$ cytotoxic concentration $\left(\mathrm{CC}_{50}\right)$ was calculated in a similar manner. The selectivity index (SI) was calculated as $\mathrm{CC}_{50} / \mathrm{IC}_{50}$ (Baba et al. 1987).

\section{Results}

The Peltophorum africanum methanol fractions were examined. The methanol fraction showed anti HIV-1 activity with R5 virus with an SI of 3. The ethyl acetate fraction showed anti HIV-1 activity with the X4 virus with an SI of 189. The butanol fraction showed anti HIV-1 activity with the R5 virus with an SI of 37 and the X4 virus with an SI of

TABLE 1. Anti-HIV-1 activity and cytotoxicity of fractions isolated from Peltophorum africanum.

\begin{tabular}{lcrrrr}
\hline \multirow{2}{*}{ Fraction no. } & \multirow{2}{*}{$\mathrm{CC}_{50}{ }^{\mathrm{a}}(\mu \mathrm{g} / \mathrm{mL})$} & \multicolumn{2}{c}{$\mathrm{IC}_{50}{ }^{\mathrm{b}}(\mu \mathrm{g} / \mathrm{mL})$} & \multicolumn{3}{c}{$S I^{\mathrm{c}}\left(C C_{50} / C_{50}\right)$} \\
& & $\mathrm{R}^{\mathrm{d}}$ & $\mathrm{X} 4^{\mathrm{e}}$ & $\mathrm{R}^{\mathrm{d}}$ & $\mathrm{X} 4^{\mathrm{e}}$ \\
\hline Methanol & 255 & 78 & $\mathrm{ND}$ & 3 & $\mathrm{ND}$ \\
Ethyl acetate & 378 & 4 & 2 & 94.5 & 189 \\
Butanol & 110 & 3 & 10 & 37 & 11 \\
Water & 125 & 1 & 8 & 125 & 15.6 \\
\hline
\end{tabular}

$\mathrm{CC}_{50}{ }^{\mathrm{a}}=$ Concentration which inhibits MAGI CCR5+ cell growth by $50 \% . \mathrm{IC}_{50}{ }^{\mathrm{b}}=$ Concentration which inhibits virus replication by $50 \%$. SI $=$ Selective index.

$R 5^{\mathrm{d}}=\mathrm{R} 5 \mathrm{HIV}-1$ JRCSF. $X 4^{\mathrm{e}}=\mathrm{X} 4 \mathrm{HIV}-1$ pNL4-3.

$N D=$ Not determined

TABLe 2. Anti-HIV-1 activity and cytotoxicity of fractions isolated from Peltophorum africanum butanol fraction.

\begin{tabular}{|c|c|c|c|c|c|}
\hline \multirow{2}{*}{ Fraction no. } & \multirow{2}{*}{$\mathrm{CC}_{50}{ }^{\mathrm{a}}(\mu \mathrm{g} / \mathrm{mL})$} & \multicolumn{2}{|c|}{$\mathrm{IC}_{50}{ }^{\mathrm{b}}(\mu \mathrm{g} / \mathrm{mL})$} & \multicolumn{2}{|c|}{$S I^{c}\left(C C_{50} / I C_{50}\right)$} \\
\hline & & $\mathrm{R} 5^{\mathrm{d}}$ & $X 4^{e}$ & $\mathrm{R} 5^{\mathrm{d}}$ & $\mathrm{X} 4^{\mathrm{e}}$ \\
\hline PA-b-1 & 100 & 7.4 & 64 & 13.5 & 1.5 \\
\hline PA-b-2 & 251 & 86 & 109 & 2.9 & 2.3 \\
\hline PA-b-3 & 489 & 199 & 41 & 2.45 & 11.9 \\
\hline PA-b-4 & $<83$ & 29.0 & 4.9 & $<2.86$ & $<16.9$ \\
\hline PA-b-5 & 756 & 5.6 & 68 & 135 & 11.1 \\
\hline PA-b-6 & 100 & 31 & 45 & 3 & 2.2 \\
\hline $\begin{array}{l}\quad \mathrm{CC}_{5} \\
\text { cell grov } \\
\text { virus rep } \\
\text { HIV-1 JR }\end{array}$ & $\begin{array}{l}=\text { Concentratio } \\
\text { h by } 50 \% . \quad \mathrm{IC}_{50} \\
\text { cation by } 50 \% \text {. } \\
\text { CSF. } X 4^{\mathrm{e}}=\mathrm{X} 4\end{array}$ & $\begin{array}{l}\text { which } \\
=\mathrm{Con} \\
S I^{c}=\mathrm{Se} \\
\text { IV-1 pI }\end{array}$ & $\begin{array}{l}\text { hibits } \\
\text { tratio } \\
\text { tive it } \\
4-3 .\end{array}$ & $\begin{array}{l}\text { MAGI } \\
\text { which } \\
\text { dex. } R 5\end{array}$ & $\begin{array}{l}\text { R5+ } \\
\text { aibits } \\
=\text { R5 }\end{array}$ \\
\hline
\end{tabular}

11 (Table 1).

The butanol fraction of Peltophorum africanum was then examined. The fraction PA-b-1 showed anti HIV-1 activity with the R5 virus with an SI of 13.5. The fraction PA-b-4 showed the anti HIV-1 activity with X4 virus with an SI of 16.9. The fraction PA-b-5 showed high anti HIV-1 activity with R5 virus with an SI of 135 (Table 2).

The ethyl acetate fraction was then examined. The ethyl acetate fraction of PA-e-2 inhibited virus replication in MAGI CCR5+ cells with an R5 virus IC $_{50}$ value of 1.8 $\mu \mathrm{g} / \mathrm{ml}, \mathrm{CC}_{50}$ of $308 \mu \mathrm{g} / \mathrm{ml}$ and an SI of 171.1. For the X4 virus, the $\mathrm{IC}_{50}$ value was $1 \mu \mathrm{g} / \mathrm{ml}, \mathrm{CC}_{50}$ was $308 \mu \mathrm{g} / \mathrm{ml}$ and an SI was 308. This fraction showed high anti-HIV-1 activity and it is from this fraction that betulinic acid was isolated. The SI value for fraction PA-e-5 using the X4 virus was 98 (Table 3). The fractionation of Peltophorum africanum is shown in Fig. 1. An ethyl acetate extract (PA-e-2) of the dry powdered stem bark of Peltophorum africanum on concentration yielded crude betulinic acid (49.6 mg), which was filtered out, with repeated chromatography (silica gel) of the filtrate, and recrystallization led to the isolation of purified betulinic acid $(23.5 \mathrm{mg})$. Similarly, repeated chro-

TABLE 3. Anti-HIV-1 activity and cytotoxicity of fractions isolated from Peltophorum africanum ethyl acetate fraction.

\begin{tabular}{crrrrr}
\hline \multirow{2}{*}{ Fraction no. } & \multirow{2}{*}{$\mathrm{CC}_{50}{ }^{\mathrm{a}}(\mu \mathrm{g} / \mathrm{mL})$} & \multicolumn{2}{c}{$\mathrm{IC}_{50}{ }^{\mathrm{b}}(\mu \mathrm{g} / \mathrm{mL})$} & \multicolumn{2}{c}{$S I^{c}\left(C C_{50} / I C_{50}\right)$} \\
& & $\mathrm{R}^{\mathrm{d}}$ & $\mathrm{X} 4^{\mathrm{e}}$ & $\mathrm{R}^{\mathrm{d}}$ & \multicolumn{1}{c}{$\mathrm{X} 4^{\mathrm{e}}$} \\
\hline PA-e-1 & 498 & 9 & 8.5 & 55.3 & 58.5 \\
PA-e-2 & 308 & 1.8 & 1 & 171.1 & 308 \\
PA-e-3 & 50 & 9.94 & 11 & 5 & 4.5 \\
PA-e-4 & 1009 & 9.9 & 98 & 102 & 10 \\
PA-e-5 & 127 & 15.2 & 1.3 & 8 & 98 \\
\hline
\end{tabular}

$\mathrm{CC}_{50}{ }^{\mathrm{a}}=$ Concentration which inhibits MAGI CCR5+ cell growth by $50 \% . \quad \mathrm{IC}_{50}{ }^{\mathrm{b}}=$ Concentration which inhibits virus replication by $50 \% . S I^{c}=$ Selective index. $R 5^{\mathrm{d}}=\mathrm{R} 5$ HIV-1 JRCSF. $X 4^{\mathrm{e}}=\mathrm{X} 4 \mathrm{HIV}-1 \mathrm{pNL} 4-3$.

TABLE 4. Potent activity of betulinic acid against X4-HIV-1 and R5-HIV-1.

Anti HIV-1 activity against HIV-1 laboratory isolates and cytotoxicity using MAGI CCR5 cells

\begin{tabular}{|c|c|c|c|c|}
\hline \multirow{3}{*}{ compound } & \multicolumn{3}{|c|}{ MAGI (CCR5-MAGI) } & \multirow{3}{*}{$\mathrm{Si}^{\mathrm{b}}$} \\
\hline & \multicolumn{2}{|c|}{$\mathrm{IC}_{50}(\mu \mathrm{g} / \mathrm{ml})^{\mathrm{a}}$} & \multirow{2}{*}{$\mathrm{CC}_{50}(\mu \mathrm{g} / \mathrm{ml})$} & \\
\hline & $\mathrm{HIV}-1_{\mathrm{NL} 4-3}$ & HIV-1 ${ }_{\text {JRCSF }}$ & & \\
\hline GL & 0.04 & & 1.65 & 41 \\
\hline BA & 0.04 & & $>0.09$ & $>2$ \\
\hline GL & & 0.58 & 1.65 & 3 \\
\hline BA & & 0.002 & $>0.09$ & $>45$ \\
\hline
\end{tabular}

${ }^{a}$ The $\mathrm{IC}_{50}$ values were determined with the MAGI assay. Cytotoxicity of the test compounds was also determined with the cell counting kit 8 . ${ }^{\mathrm{b}}$ SI, selectivity index, $\mathrm{CC}_{50} / \mathrm{IC}_{50}$. BA, betulinic acid and GL, glycyrrhizin. 
matography of the ethyl acetate extract of Peltophorum africanum PA-e-4 yielded catechin and PA-b-2 yielded bergenin.

We tested betulinic acid and glycyrrhizin against HIV$1_{\mathrm{NL} 4-3}(\mathrm{X} 4 \mathrm{HIV}-1)$ and HIV-1 $1_{\text {JRCSF }}(\mathrm{R} 5 \mathrm{HIV}-1)$ using MAGICCR5 cells as target cells. As assessed in the MAGI assay, the $\mathrm{IC}_{50}$ using $\mathrm{HIV}-1_{\mathrm{NL} 4-3}$ was $0.04 \mu \mathrm{g} / \mathrm{ml}$ for betulinic acid and $0.04 \mu \mathrm{g} / \mathrm{ml}$ for glycyrrhizin (Table 4 ). In the same antiviral assay using HIV- $1_{\text {JRCSF}}$, the $\mathrm{IC}_{50}$ value was 0.002 $\mu \mathrm{g} / \mathrm{ml}$ for betulinic acid and $0.58 \mu \mathrm{g} / \mathrm{ml}$ for glycyrrhizin. The $\mathrm{CC}_{50}$ determined using cell counting kit 8 , was $>0.09$ $\mu \mathrm{g} / \mathrm{ml}$ for betulinic acid and $1.65 \mu \mathrm{g} / \mathrm{ml}$ for glycyrrhizin.

\section{Discussion}

There has been a trend towards using traditional medicines to treat various diseases, especially in developing countries. Medicinal plant extracts are chemically complex and diverse. They could provide a safer and more effective platform for newer drugs and could lead to better success than routine random screening. Botanical extracts provide a wide spectrum of biological and pharmacological properties, including cytoprotective, anti cancer, anti-inflammatory, immunomodulative and anti-infectious activities (Wang et al. 2006) Many compounds with anti-HIV effects have been screened out from botanicals and found to inhibit HIV at nearly all stages of the viral life cycle.

In the present study, extracts of Peltophorum africanum were shown to have anti-HIV activities, especially fraction PA-e-2. It is interesting to note that we could isolate the inhibitory molecule betulinic acid from the high active fraction, PA-e-2. Our study shows that betulinic acid inhibits both X4-tropic virus and R5-tropic virus, suggesting that betulinic acid is a potentially useful inhibitor of different HIV-1 strains. The betulinic acid inhibitory activity was found on HIV-1 111B (X4 tropic strain) infection to $\mathrm{H} 9$ cells; the $\mathrm{EC}_{50}$ value was $1.4 \mu \mathrm{M}$ and $\mathrm{CC}_{50}$ was $13 \mu \mathrm{M}$ with an SI of 9.3 (Fujioka et al. 1994).

The possible mechanism of action of betulinic acid has recently been elucidated using betulinic acid derivatives (BAD) that act as HIV-1 entry inhibitors. BAD are synthesized using betulinic acid as a scaffold and their viral targets depend on where their side chains reside. One such BAD, IC9564, inhibits HIV-1 by targeting the V3 loop of gp120, and it competed with the binding of V3-specific monoclonal antibodies 447-52D and 39F to HIV-1 11lB (X4) gp120. IC9564 inhibited the binding of these monoclonal antibodies to gp120 in a dose-dependent manner. Since IC9564 can inhibit both R5 and X4 viruses, it also competed effectively with the binding of 447-52-D to HIV-1 Ba-L gp120 (R5). The binding of BAD likely interferes with the interactions of gp120 and the chemokine receptors. IC9564 at 5 $\mu \mathrm{g} / \mathrm{ml}$ strongly inhibited the binding of HIV-1 Ba-L gp120/ CD4 (R5) or HIV-1 11lB gp120/CD4 (X4) complexes to HOS.CCR5 or HOS.CXCR4 cells. Additionally, Clade C viruses, which account for approximately $50 \%$ of all HIV-1 isolates around the world and are predominant in sub-Saha- ran Africa, are sensitive to the BAD at submicromolar concentrations. Clade $\mathrm{C}$ viruses were more sensitive to the inhibition of A43-D, which reduced clade $\mathrm{C}$ virus infection by $50 \%\left(\mathrm{IC}_{50}\right)$ at an average concentration of $0.206 \mu \mathrm{M}$ (Lai et al. 2008).

Several triterpene compounds have been described to have HIV-1 antiviral activity. In a previous report, glycyrrhizin inhibited the R5 HIV replication in cultures of fresh peripheral blood monocytes treated with 1-methyladenosine (PBM/MA) in a dose dependent manner. In GL treated fresh PBM/MA $(100 \mu \mathrm{g} / \mathrm{ml}), 85 \%$ of HIV replication was inhibited. (Takei et al. 2005). Previous studies done in our lab have also shown that glycyrrhizin inhibits the binding of anti-CCR5 monoclonal antibody 2D7 to target cells (unpublished data).

It should also be noted that betulinic acid probably acts as a maturation inhibitor by inhibiting viral assembly/viral budding. In a study by Zhou et al. (2004), dimethylsuccinyl-betulinic acid (DSB), a derivative of betulinic acid, inhibited HIV-1 replication and functioned at a late stage of the virus life cycle but did not inhibit the HIV-1 protease in vitro or interfere with virus particle assembly or release. DSB specifically delayed the cleavage of Gag between the capsid and p2, resulting in delayed formation of the mature viral core and reduced HIV-1 infectivity (Zhou et al. 2004; Aiken and Chen 2005).

Bessong et al. (2005) reported that several active compounds could be isolated from the extracts of Peltophorum africanum. Using a radioactive cell-free assay, (+)-catechin, a flavonoid, was isolated from the stem bark of Peltophorum africanum, and shown to inhibit the 3 '-end processing activity of HIV-1 IN by as much as $65 \%$ at $100 \mu \mathrm{M}$, but had no activity on HIV-1 RT (Bessong et al. 2005). Derivatives of catechin such as epicatechin and epigallocatechin gallate have been shown to inhibit HIV-1 RT in the micromolar range (Tillekeratne et al. 2002).

Bergenin, a C-galloylglycoside was also isolated from Peltophorum africanum in the present study. Bergenin has been previously isolated from Peltophorum africanum (Mebe and Makuhunga 1992) and several other plants, namely the roots of Astilbe thumbergii (Han et al. 1998) and the aerial parts of Fluggea virosa (Pu et al. 2002). In another study, bergenin had no activity against the RDDP and RNase H of HIV-1 RT and the 3'-end processing activity of HIV-1 IN, even at a concentration of $500 \mu \mathrm{M}$ (Bessong et al. 2005). Elsewhere, bergenin showed weak anti-HIV-1 activity in C8166 cells infected with $\mathrm{HIV}-1_{\mathrm{MN}}$ (X4 virus) with an $\mathrm{EC}_{50}$ value of $40 \mu \mathrm{g} / \mathrm{ml}$. Further experiments showed that bergenin inhibited the binding of GP120 to sCD4 in a dose-dependent manner (Piacente et al. 1996).

It is worth noting that betulinic acid and its analogues have been used for the treatment of various infections for decades and have an acceptable oral bioavailability (Bessong et al. 2005). However, incidents of poisoning have been reported (Hamouda et al. 2000). Because of the low amount of betulinic acid in Peltophorum africanum, large doses of 
crude extracts of the stem bark need to be consumed. The clinical efficacy of betulinic acid in Peltophorum africanum should therefore be carefully evaluated, because our knowledge of the toxicity profiles in humans upon administration of this medicinal plant is limited. These data suggest that betulinic acid and its analogues could be used as potential therapeutics for HIV-1.

\section{Conclusion}

A systematic evaluation against HIV-1 of one selected traditionally used South African medicinal plant was done. Peltophorum africanum contains an anti-HIV-1 constituent, betulinic acid, which inhibits HIV-1. There is therefore a rationale for the traditional use of the stem bark of Peltophorum africanum in treating HIV/AIDS and related opportunistic infections.

\section{Acknowledgments}

This work was supported by Special Educational Grant from Ministry of Education, Culture, Sports, Science and Technology, by Grant-in-Aid for Scientific Research from Ministry of Health, Labour and Welfare and by grant of Asia and Africa program of Tohoku University. Financial support on the South African side was provided by the National Research Foundation and the Department of Science and Technology under the aegis of the South Africa-Japan Research Collaborative Agreement. MAGICCR5 cells were obtained from Dr. Overbaugh through NIH AIDS Research \& Reference Program. Stocks of HIV-1 strain pNL4-3 (Adachi et al. 1986) (X4) and JRCSF virus (R5) (Takeuchi et al. 2002) were obtained from Drs. A. Adachi and Y. Koyanagi, respectively. We are grateful to Mr. Brent Bell for reading the manuscript.

\section{References}

Adachi, A., Gendelman, H.E., Koenig, S., Folks, T., Willey, R., Rabson, A. \& Martin, M.A. (1986) Production of acquired immunodeficiency syndrome-associated retrovirus in human and nonhuman cells transfected with an infectious molecular clone. J. Virol., 59, 284-291.

Aiken, C. \& Chen, C.H. (2005) Betulinic acid derivatives as HIV-1 antivirals. Trends Mol. Med., 11, 31-36.

Baba, M., Konno, K., Shigeta, S. \& De Clercq, E. (1987) In vitro activity of (S)-9-(3-hydroxy-2-phosphonylmethoxypropyl) adenine against newly isolated clinical varicella-zoster virus strains. Eur. J. Clin. Microbiol., 6, 158-160.

Barre-Sinoussi, F., Chermann, J.C., Rey, F., Nugeyre, M.T., Chamaret, S., Gruest, C., Dauguest, C., Axler-blin, C., Vézinet-Brun, F., Rouzioux, C., Rozenbaum, W. \& Montagnier, L. (1983) Isolation of a T-lymphotropic retrovirus from a patient at risk for acquired immune deficiency syndrome (AIDS). Science, 220, 868-871.

Bessong, P.O. \& Obi, C.L. (2006) Ethnopharmacology of human immunodeficiency virus in South Africa- a minireview. Afr. $J$. Biotech., 5, 1693-1699.

Bessong, P.O., Obi, C.L., Andreola, M., Rojas L.B., Pouysegu, L., Igumbor, E., Meyer, J.J.M., Quideau, S. \& Litvak, S. (2005) Evaluation of selected South African medicinal plants for inhibitory properties against human immunodeficiency virus type 1 reverse transcriptase and integrase. J. Ethnopharmacol., 99, 83-91.

Bessong, P.O., Obi, C.L., Igumbor, E., Andreola, M. \& Litvak, S. (2004) In vitro activity of three South African medicinal plants against human immunodeficiency virus type 1 reverse transcriptase. Afr. J. Biotechnol., 3, 555-559.

Chackerian, B., Long, E.M., Luciw, P.A. \& Overbaugh, J. (1997) Human immunodeficiency virus type 1 co-receptors participates in post entry stages of the virus replication cycle and function in SIV infection. J. Virol., 71, 3932-3939.

De Clercq, E. (2000) Current lead natural products for the chemotherapy of human immuno deficiency virus infection. Med. Res. Rev., 20, 323-349.

Felgner, J.H., Kumar, R., Sridhar, C.N., Wheeler, C.J., Tsai, J.Y., Border, R., Ramsey, P., Martin, M. \& Feigner, L.P. (1993) Enhanced gene delivery and mechanism studies with a novel series of cationic lipid formulations. J. Biol. Chem., 269, 2550-2561.

Flosh, V., Audrezet, M.P., Guillaume, C., Gobin, E., Bolch, Le.G., Clement, J.C., Yaouanc, J.J., Abbayes, Des.H., Mercier, B., Leroy, J.P., Abgrall, J.F. \& Ferec, C. (1998) Transgene expression kinetics after transfection with cationic phosphonolipids in hematopoietic non adherent cells. Biochim. Biophys. Acta., 1371, 53-70.

Francois, C. \& Hance, A.J. (2004) HIV drug resistance. N. Engl. J. Med., 350, 1023-1035.

Fujioka, T. \& Kashiwada, Y. (1994) Anti-AIDS agents, 11. Betulinic acid and platanic acid as anti-HIV principles from Syzigium claviflorum, and the anti-HIV activity of structurally related triterpenoids. J. Nat. Prod., 57, 243-247.

Gallo, R.C., Sarin, P.S., Gelmann, E.P., Robert-Guroff, M., Richardson, E., Kalyanaraman, V.S., Mann, D., Sidhu, G.D., Stahl, R.E., Zolla-Pazner, S., Leibowitch, J. \& Popovic, M. (1983) Isolation of human T-cell leukemia virus in acquired immune deficiency syndrome (AIDS). Science, 220, 865-867.

Gulick, R.M., Mellors, J.W., Havlir, D., Eron, J.J., Gonzalez, C., Mcmahon, D., Richman, D.D., Valentine, F.T., Jonas, L., Meibohm, A., Emini, E.A. \& Chodakewitz, J.A. (1997) Treatment with indinavir, zidovudine, and lamivudine in adults with human immunodeficiency virus infection and prior antiretroviral therapy. N. Engl. J. Med., 337, 734-739.

Hamouda, C., Amamou, M., Thabet, H., Yacoub, M., Hedhili, A. \& Bescharnia, F. (2000) Plant poisonings from herbal medication admitted to a Tunisian toxicology intensive care unit 1983-1998. Vet. Hum. Tox., 42, 137-141.

Han, L.K., Ninomiya, H., Taniguchi, M., Kimura, Y. \& Okuda, H. (1998) Norepinephrine-augmenting lipolytic effectors from Astilbe thunbergii rhizomes. J. Nat. Prod., 61, 1006-1011.

Hattori, T., Ikematsu, S., Koito, A., Matsushita, S., Maeda, Y., Hada, M., Fujimaki, M. \& Takatsuki, K. (1989) Preliminary evidence for inhibitory effect of glycyrrhizin on HIV replication in patients with AIDS. Antiviral. Res., 11, 255-261 13.

Ito, M., Sato, A., Hirabayashi, K., Tanabe, F., Shigeta, S., Baba, M., De Clercq, E., Nakashima, H. \& Yamamoto, N. (1988) Mechanism of inhibitory effect of glycyrrhizin on replication human immunodeficiency virus (HIV). Antiviral Res., 10, 289-298.

Kong, J.M., Goh, N.K., Chia, L.S. \& Chia, T.F. (2003) Recent advances in traditional plant drugs and orchids. Acta Pharmacol. Sin., 24, 7-21.

Lall, N., Das, S.M., Hazra, B. \& Meyer, J.J. (2003) Antimycobacterial activity of diospyrin derivatives and a structural analogue of diospyrin against Mycobacterium tuberculosis in vitro. $J$. Antimicrob. Chemother., 51, 435-438.

Lall, N. \& Meyer, J.J. (2001) Inhibition of drug sensitive and drug resistant strains of Mycobacterium tuberculosis by diospyrin, isolated from Euclea natalensis. J. Ethnopharamacol., 78, 213-216.

Lai, W., Ho, P., Huang, L., Li, Z., Montefiori, D. \& Chen, C. (2008) Betulinic acid derivatives that target gp120 and inhibit multiple genetic subtypes of HIV-1. J. Antimicrob. Chemother., 52, 128-136.

Mebe, P.P. \& Makuhunga, P. (1992) 11-p-Coumaric acid ester of bergenin from Peltophorum africanum. Phytochemistry, 31, 3286-3287. 
Morris, K. (2002) South Africa tests traditional medicines. Lancet Infect. Dis., 2, 319.

Obi, C.L., Potgieter, N., Masebe, T., Mathebula, H. \& Molobela, P. (2003) In vitro antibacterial activity of Venda medicinal plants. S. Afri. J. Botany., 69, 199-203.

Obi, C.L., Potgieter, N., Randima, L.P., Mavhungu, N.J., Musie, E., Bessong, P.O., Mabogo, D.E.N. \& Mashimbye, J. (2002) Antibacterial activity of five medicinal plants against some medically significant human bacteria. S. Afr. J. Sci., 98, 25-28.

Piacente, S., Pizza, C., De Tommasi, N. \& Mahmood, N. (1996) Constituents of Ardista japonica and their in vitro anti HIV activity. J. Nat. Prod., 59, 565-569.

Perelson, A.S., Essunger, P., Cao, Y., Vesanen, M., Hurley, A., Saksela, K., Markowitz, M. \& Ho, D.D. (1997) Decay characteristics of HIV-1-infected compartments during combination therapy. Natur., 387, 88-191.

Pu, H.L., Huang, X., Zhao, J.H. \& Hong, A. (2002) Bergenin is the antiarrhymic principle of Fluggea virosa. Planta Med., 68, 372-374.

Takei, M., Kobayashi, M., Li, X.D., Pollard, R.B. \& Suzuki, F. (2005) Glycyrrhizin inhibits R5 HIV replication in peripheral blood monocytes treated with 1-methyladenosine. Pathobiology, 72, 117-123.

Takeuchi, H., Suzuki, Y., Tatsumi, M., Hoshino, H., Daar, E.S. \&
Koyanagi Y. (2002) Isolation and characterization of an infectious HIV type 1 molecular clone from a patient with primary infection. AIDS Res. Hum. Retroviruses, 18, 1127-1133.

Tillekeratne, L.M.V., Sherette, A., Fulmer, J.A., Hupe, D., Gabbara, S., Peliska, J.A. \& Hudson, R.A. (2002) Differential inhibition of polymerase and strand-transfer activities of HIV-1 reverse transcriptase. Bio. Med. Che. Let., 12, 525-528.

UNAIDS/WHO (2005) AIDS Epidemic Update, UNAIDS, Geneva, Switzerland, p. 17.

Uchida, B., Maeda, Y. \& Mitsuya, H. (1997) HIV-1 protease does not play a role in the early stages of HIV-1 infection. Antiviral Res., 36, 107-113.

Vlietinck, A.J., De Bruyne, T., Apers, S. \& Pieters, L.A. (1998) Plant-derived leading compounds for chemotherapy of human immunodeficiency virus (HIV) infection. Planta Med., 64, 97-109.

Wang, R., Gu, Q., Yang, L., Chen, J., Li, S. \& Zheng, Y. (2006) Anti-HIV-1 activities of extracts from the medicinal plant Rhus chinensis. J. Ethnopharmacol., 105, 269-273.

Zhou, J., Yuan, X., Dismuke, D., Forshey, B.M., Lundquist, C., Lee, K.H., Aiken, C. \& Chen, C.H. (2004) Small-molecule inhibition of human immunodeficiency virus type 1 replication by specific targeting of the final step of virion maturation. $J$. Virol., 78, 922-929. 